\title{
ANALISIS KINERJA KEUANGAN DENGAN METODE ECONOMIC VALUE ADDED (EVA) PADA PT. FAST FOOD INDONESIA Tbk.
}

\author{
Fatichatur Rachmaniyah ${ }^{1}$ \\ Arief Y us wanto Nugroho ${ }^{2}$ \\ Fakultas Ekonomi Universitas Islam Darul 'Ulum Lamongan \\ Fatichaturrachmaniyah@unisda.ac.id \\ Ariefyuswanto@unisda.ac.id
}

\begin{abstract}
This study aims to analyze the financial performance of PT. Fast Food Indonesia in 2013-2017 with the approach of Economic Value Added (EVA). This type of research is descriptive qualitative research with quantitative data types, because this study examines a case at PT. Fast Food Indonesia Tbk which is carried out intensively, deeply and comprehensively. The research analysis of financial performance of PT. Fast Food Indonesia, produces EVA>O (positive value), this can be said that the company has good financial performance. However, when viewed from the accumulation of calculation data from the 2013-2017 period, the EVA value fluctuated quite significantly and tended to decline, but it still could produce economic added value.
\end{abstract}

Keywords: Financial Performance, EVA

\begin{abstract}
Abstrak: Penelitian ini bertujuan untuk menganalisis kinerja keuangan PT. Fast Food Indonesia tahun 2013-2017 dengan pendekatan Economic Value Added (EVA). Jenis Penelitian ini merupakan penelitian kualitatif deskriptif dengan jenis data kuantitatif, karena penelitian ini menelaah suatu kasus pada PT. Fast Food Indonesia Tbk yang dilakukan secara intensif, mendalam dan komprehensif. Penelitian analisis kinerja keuangan PT. Fast Food Indonesia ini, menghasilkan nilai EVA > 0 (bernilai positif), hal ini dapat dikatakan perusahaan memiliki kinerja keuangan yang baik. Namun, jika dilihat dari akumulasi data perhitungan dari periode 2013-2017, nilai EVA berfluktuasi yang cukup signifikan dan cenderung menurun, tetapi masih dapat menghasilkan nilai tambah ekonomis.
\end{abstract}

Kata Kunci: Kinerja Keuangan, EVA

\section{PENDAHULUAN}

Makanan siap saji telah menjadi suatu kebutuhan yang cukup penting bagi masyarakat saat ini, khususnya pada masyarakat milenial. Oleh sebab itu, banyak berdirinya usaha makanan siap saji di Indonesia yang bersaing untuk menarik konsumen dengan berbagai menu jenis tawaran makanan siap saji yang menarik. Hal ini sangat penting bagi perusahaan dalam meningkatkan nilai tambah ekonomis guna meningkatkan daya saing dengan kompetitor.

Menganalisis kinerja keuangan suatu perusahaan sebelum melakukan investasi itu sangat penting bagi penanam modal. Jika kinerja keuangan perusahaan tersebut baik, maka investor tidak akan ragu dalam menginvestasikan dananya pada perusahaan tersebut. Kinerja keuangan suatu perusahaan dapat dilihat dari laporan keuangan. Laporan keuangan 
merupakan media informasi yang merangkum semua aktivitas perusahaan. Tujuan menganalisis laporan keuangan suatu perusahaan guna mendapatkan informasi mengenai kondisi perusahaan tersebut sebagai dasar pengambilan keputusan baik bagi pihak manajemen perusahaan maupun pihak investor (Harahap, 2010).

Berbagai macam alat analisis kinerja keuangan, peneliti memilih dengan metode EVA. Pengukuran kinerja keuangan dengan metode EVA ini berbeda dengan metode rasio keuangan pada umumnya, pada pendekatan EVA ini mengukur nilai tambah yang dihasilkan suatu perusahaan dengan cara mengurangi beban biaya modal yang dihasilkan sebagai akibat investasi yang dilakukan. Penelitian ini bertujuan untuk menganalisis kinerja keuangan PT. Fast Food Indonesia dengan pendekatan Economic Value Added (EVA).

\section{TINJAUAN PUSTAKA}

\section{Kinerja Keuangan}

Menurut Standar Akuntansi Keuangan menyatakan bahwa kinerja keuangan adalah cara pengujian terstruktur yang berasal dari laporan keuangan dan sistem operasi perusahaan. Hal tersebut yang bertujuan untuk menyampaikan tentang kinerja keuangan dan arus kas yang bermanfaat bagi investor guna dalam pembuatan keputuasan investasinya.
Economic Value Added (EVA)

Menurut (Rudianto, 2013), Economic Value Added (EVA) merupakan pengukuran kinerja keuangan berdasarkan nilai dari biaya untuk memperoleh nilai tambah, sehingga metode EVA cocok sebagai alat untuk mengendalikan operasi perusahaan.

Kelebihan konsep EVA adalah bermanfaat sebagai penilai kinerja keuangan yang berfokus pada penciptaan nilai, yang mana akan membuat perusahaan lebih memperhatikan struktur modal. Penilaian kinerja keuangan dengan pendekatan EVA menyebabkan fokus perhatian manajemen sesuai dengan kepentingan pemegang saham (Hanafi, 2016).

Berikut ini tolak ukur penilaian EVA, yaitu:

1. Nilai EVA > 0, artinya nilai EVA bernilai positif, perusahaan memiliki kinerja keuangan yang baik.

2. Nilai $\mathrm{EVA}=0$, artinya nilai EVA berada di posisi break even point, perusahaan tidak memiliki kelebihan laba untuk menambah nilai tambah ekonomis.

3. Nilai EVA $<0$, artinya nilai EVA bernilai positif, perusahaan memiliki kinerja keuangan yang tidak baik.

\section{KERANGKA PIKIR}

Berdasarkan rumusan tujuan penelitian, maka berikut desain kerangka pikir penelitian ini, sebagai berikut: 


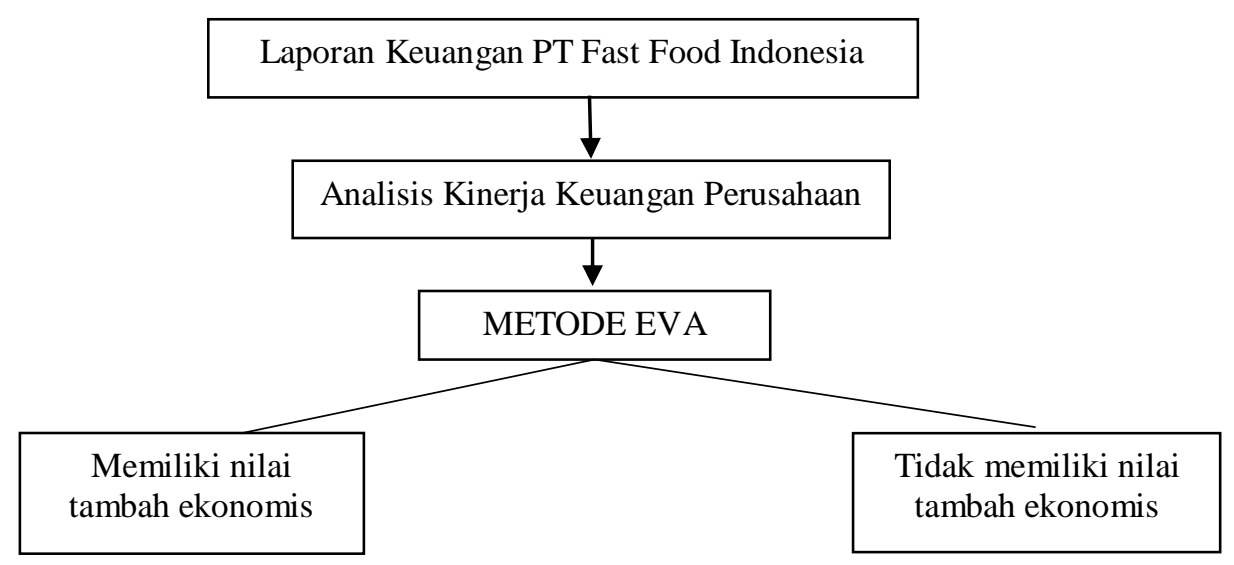

Gambar 1: Kerangka Pikir Penelitian

\section{HIPOTESIS}

Berdasarkan penjabaran diatas, maka hipotesis penelitian ini adalah:

Ha : Kinerja keuangan PT Fast Food Indonesia pada periode 2013-2017 memiliki nilai tambah ekonomis

$\mathrm{H}_{0}$ : Kinerja keuangan PT Fast Food Indonesia pada periode 2013-2017 tidakmemiliki nilai tambah ekonomis

\section{METODE PENELITIAN}

Jenis Penelitian ini merupakan penelitian kualitatif deskriptif dengan jenis data kuantitatif, karena penelitian ini menelaah suatu kasus pada PT. Fast Food Indonesia Tbk yang dilakukan secara intensif, mendalam dan komprehensif (Sugiyono, 2013). Sumber data menggunakan data sekunder, yaitu laporan keuangan PT. Fast Food Indonesia Tbk selama lima tahun (20132017), yang diperoleh dari BEI melalui situs idx.co.id

\section{Metode Analisis Data}

Metode analisis data laporan keuagan penelitian ini menggunakan pendekatan Economic Value Added (EVA), berikut langkah-langkah perhitungannya, (Brigham, 2010):

1. Menghitung NOPAT (Net Operating Profit After Tax)
NOPAT $=$ EAT + Bunga

2. Menghitung IC (Invested Capital)

$\mathrm{IC}=$ Total Hutang + Ekuitas

3. Menghitung WACC (Weighted Average Cost of Capital)

WACC $=($ D. rd $)(1-$ Tax $)+($ E.re $)$
Ket:
D = Tingkat modal dari hutang
Rd = Biaya hutang jangka pendek
Tax = Tingkat pajak penghasilan
E = Tingkat modal dari ekuitas
Re = Tingkat biaya modal

4. Menghitung Capital Charges

Capital Charges $=$ WACC. IC

5. Menghitung EVA (Economic Value Added)

EVA $=$ NOPAT - Capital Charges

\section{HASIL DAN PEMBAHASAN}

Berikut hasil analisis kinerja keuangan dari PT. Fast Food Indonesia Tbk, yaitu:

1. Berdasarkan hasil yang diperoleh, NOPAT dari tahun 2013 sampai dengan 2017 mengalami penurunan. Hal ini disebabkan data laba bersih 
perusahaan dari tahun 2013 sampai 2017 mengalami penurunan, tetapi biaya bunga perusahaan dari tahun
2013 sampai 2017 mengalami peningkatan.

Tabel 1 Perhitungan NOPAT

(dalam ribuan rupiah)

\begin{tabular}{|c|c|c|c|}
\hline Th & EAT & $\begin{array}{c}\text { Biaya } \\
\text { Bunga }\end{array}$ & NOPAT \\
\hline 2013 & 229.054 .524 & 8.571 .296 & 237.625 .820 \\
\hline 2014 & 206.045 .984 & 20.553 .240 & 226.589 .224 \\
\hline 2015 & 156.280 .628 & 20.643 .987 & 176.994 .615 \\
\hline 2016 & 152.046 .069 & 20.788 .643 & 172.834 .712 \\
\hline 2017 & 105.021 .728 & 21.323 .553 & 126.337 .281 \\
\hline
\end{tabular}

Sumber: data olahan

2. Berdasarkan hasil perhitungan dari invested capital dalam tahun 2013 sampai 2016, mengalami peningkatan. Namun, di tahun 2017 mengalami penurunan dari tahun 2016, sebesar Rp 95.119.544.000

Tabel 2 Perhitungan Invested Capital

(dalam ribuan rupiah)

\begin{tabular}{|c|c|c|c|c|}
\hline Th & Tot Hutang & Ekuitas & $\begin{array}{c}\text { Hutang } \\
\text { Jangka } \\
\text { Pendek }\end{array}$ & IC \\
\hline 2013 & 717.263 .541 & 830.719 .484 & 422.292 .264 & 1.125 .689 .760 \\
\hline 2014 & 791.183 .187 & 990.722 .806 & 454.121 .516 & 1.327 .459 .478 \\
\hline 2015 & 972.152 .888 & 1.100 .971 .776 & 535.524 .358 & 1.575 .622 .735 \\
\hline 2016 & 969.470 .123 & 1.193 .163 .685 & 499.174 .755 & 1.662 .459 .734 \\
\hline 2017 & 1.194 .691 .040 & 1.114 .971 .331 & 789.861 .980 & 1.567 .340 .190 \\
\hline \multicolumn{5}{|c}{ Sumber: data olahan } \\
\hline
\end{tabular}

3. Berdasarkan hasil data perhitungan menunjukkan bahwa nilai WACC mengalami penurunan yang cukup signifikan dari tahun ke tahun. Hal ini dapat dinyatakan bahwa perusahaan Fast Food Indonesia memiliki nilai rata-rata tertimbang biaya modal yang kecil, yang mana dapat menggambarkan bahwa tingkat pengembalian investasi minimum yang diharapkan oleh investor.

Tabel 3

Perhitungan Weighted Average Cost of Capital (dalam ribuan rupiah)

\begin{tabular}{|c|c|c|c|c|c|c|}
\hline Th & D & rd & Tax & E & re & WACC \\
\hline 2013 & 0,463 & 0,032 & 0,767 & 0,536 & 0,276 & $14,79 \%$ \\
\hline 2014 & 0,444 & 0,061 & 0,765 & 0,556 & 0,208 & $11,55 \%$ \\
\hline 2015 & 0,457 & 0,053 & 0,769 & 0,543 & 0,142 & $7,70 \%$ \\
\hline 2016 & 0,448 & 0,044 & 0,719 & 0,552 & 0,127 & $7,02 \%$ \\
\hline 2017 & 0,517 & 0,053 & 0,787 & 0,473 & 0,095 & $4,52 \%$ \\
\hline \multicolumn{7}{|c|}{ Sumber: data olahan }
\end{tabular}

4. Capital Charges merupakan aliran kas yang dibutuhkan untuk mengganti para investor atas risiko usaha dari modal yang diinvestasikan. Berdasarkan hasil perhitungan pada table 4, menunjukkan nilai Capital 
Charges mengalami penurunan dari periode 2013 sampai dengan 2017.

Tabel 4 Perhitungan Capital Charges

(dalam ribuan rupiah)

\begin{tabular}{|c|c|c|c|}
\hline Th & IC & WACC & $\begin{array}{c}\text { Capital } \\
\text { Charges }\end{array}$ \\
\hline 2013 & 1.125 .689 .760 & $14,79 \%$ & 166.489 .513 \\
\hline 2014 & 1.327 .459 .478 & $11,55 \%$ & 153.359 .108 \\
\hline 2015 & 1.575 .622 .735 & $7,70 \%$ & 117.396 .223 \\
\hline 2016 & 1.662 .459 .734 & $7,02 \%$ & 116.775 .903 \\
\hline 2017 & 1.567 .340 .190 & $4,52 \%$ & 68.886 .549 \\
\hline \multicolumn{3}{|c|}{ Sumber: data olahan } \\
\hline
\end{tabular}

5. Hasil perhitungan analisis kinerja keuangan metode EVA pada perusahaan Fast Food Indonesia, menunjukkan nilai yang fluktuasi. Namun, nilai masih EVA $>0$ (bernilai positif), hal ini dapat dinyatakan bahwa PT. Fast Food Indonesia Tbk. masih mampu menghasilkan nilai tambah ekonomis bagi pemegang saham atau investor.

Tabel 5

Perhitungan Economic Value Added

(dalam ribuan rupiah)

\begin{tabular}{|c|c|c|c|}
\hline Th & NOPAT & $\begin{array}{c}\text { Capital } \\
\text { Charges }\end{array}$ & EVA \\
\hline 2013 & 237.625 .820 & 166.489 .513 & 71.136 .307 \\
\hline 2014 & 226.589 .224 & 153.359 .108 & 73.230 .116 \\
\hline 2015 & 176.994 .615 & 117.396 .223 & 59.598 .392 \\
\hline 2016 & 172.834 .712 & 116.775 .903 & 56.058 .809 \\
\hline 2017 & 126.337 .281 & 68.886 .549 & 57.450 .732 \\
\hline
\end{tabular}

Sumber: data olahan

\section{SIMPULAN DAN SARAN}

Berdasarkan hasil pembahasan penelitian ini dapat disimpulkan bahwa kinerja keuangan PT. Fast Food Indonesia Tbk. cukup baik yang mana menghasilkan nilai EVA > 0 (bernilai positif), sehingga dapat dikatakan perusahaan masih mampu menghasilkan nilai tambah ekonomis bagi pemegang saham atau investornya.

Nilai EVA yang dihasilkan cukup berfluktuasi yang cenderung menurun, tetapi masih dapat menghasilkan nilai tambah ekonomis. Hal ini harus diperhatikan oleh pihak manajemen PT. Fast Food Indonesia Tbk. untuk meningkatkan kinerja keuangan perusahaan yang akan menciptakan nilai tambah ekonomis serta meningkatkan dan mempertahankan nilai EVA pada setiap tahunnya.

\section{DAFTAR PUSTAKA}

Brigham \& Houston. 2010. Dasar-dasar Manajemen Keuangan. Jakarta: Salemba Empat.

Hanafi, Mamduh. 2016. Manajemen Keuangan. BPFE: Yogyakarta.

Harahap, Sofyan S. 2010. Analisis Kritis atas Laporan Keuangan. Jakarta: Rajawali Press.

Ikatan Akuntansi Indonesia. 2012. Standar Akuntansi Keuangan. Salemba Empat. Jakarta. 
Rudianto. 2013. Akuntansi Manajemen Informasi untuk Pengambilan

Sugiyono. 2013. Metode Penelitian Keputusan Strategis. Jakarta:

Bisnis. Bandung.

Alfabeta

Erlangga. 